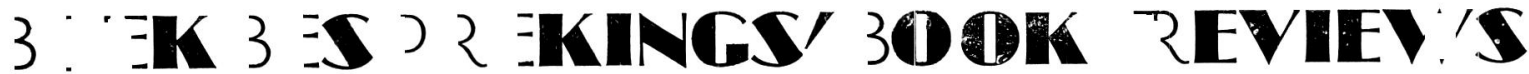

\section{MARTIN KITCHEN: A MILITARY HISTORY OF GERMANY: From the Eighteenth Century to the Present day.}

Weidenfeld \& Nicholson, 1975, pp. 384.

The central role of the army in the historical development of Germany has long been worried-at by historians and has formed the subject of a number of specialised studies. Yet since the publicaton of Gordon A. Craig's The Politics of the Prussian Army 1640-1915 (1955) and Karl Demeter's The German Officer Corps in Society and State 1640-1935 (1965), there has been no attempt to synthesize the findings of these monographs into a book capable of appealing to the general reader until the publication of A Military History of Germany.

Martin Kitchen's basic theme is that the army in Germany has played a crucial role in maintaining an anachronistic social order and in impending social change. 'Social Change', a concept demandng critical scrutiny, is taken as read by Kitchen as meaning the establishment of some form of socialist state.

We are presented with interesting insights into an army having a profound impact on German society, yet isolated from that society by virtue of its highly stratified social structure, its peculiaristic code of honour, its stress on organic unity and intensive discipline as apposed to individualism and its antipathy towards the Social Democratic movement. The Prusso-German army, Kitchen contends, engendered political instability by being ill-attuned to the realities of the day.

Kitchen underlines the oft-fatal determination of the officer-aristocrats to resist change even when it had become a political and military necessity. For instance, the Schlieffen plan of 1905 was

.... an inflexible and essentially unrealistic strategic concept which had a disastrous effect on German diplomacy ... . Fearing that the officer corps might become dangerous liberal and that the men would be social democrats and that the army would thus no longer be reliable as an instrument of domestic oppression, the army rejected the general staff's request for large increases. As a result the army did not have the men it needed if its strategic plan was to have a reasonable chance of success.'

But was the Schlieffen plan 'essentially unrealistici'? It so nearly worked. Were it not for the tenacious defence of the BEF at Mons the Germans could well have overrun France.

A number of Kitchen's statements are insufficiently substantiated. With respect to the extract above the reader is left in the dark as to the nature of the dichotomy between the army command and the general staff. In discussing the mobilization of the Prussian army immediately prior to the humiliation of Olmutz he remarks that 'there is evidence that the mobilization was deliberately retarded and sabotaged by the officers who were strongly opposed to the idea of a war which seemed to be as much for liberalism as for Prussian hegemony.' What this evidence is he does not say. The regrettable omission of footnotes in the book reinforces the impression of an unsystematic and undocumented approach. And this is unfortunate, for $\mathrm{Mr}$ Kitchen's earlier and more specialized work, The German Officer Corps 1890-1914 (1968), shows that he is well acquainted with unpublished material.

The author is too indiscriminate in his condemnation of the German military system and its members. Why did the Prusso-German army with its socially-exclusive officer corps enjoy such military successes and serve as a model for other armies? Despite their privileged position the German officer corps were not necessarily indifferent to the need for reform. There is a danger of compartmentalizing a particular class however rigid and uniform their outlook might appear. There is a distinction between a reactionary and a conservative.

Although Kitchen aims to demonstrate how the military history of Germany illuminates 'the changing nature of militarism under different forms of social organization: under declining feudalism, under industrialization, under parliamentary democracy, under facism and under advanced capitalism', he never really explores the complexity of the pheno- 
menon of militarism. Militarism cannot merely be identified with military personnel; civilian militarists such as D'Annunzio, Barrés, Theodore Roosevelt and Treitschke have proclaimed the virtues of war.

Moreover, there are no meaningful comparisons to armies in other societies and countries. Max Weber's thesis that external pressure has a vital determining influence upon the evolution of a state's socio-political structure, also has relevance. It can be argued that Prussia's history illustrates that armies become influential in countries which experience foreign pressure constantly.

Although the army was undoubtedly a key factor in shaping the authoritarian Bismarckian Reich, as Kitchen rightly declares, the intellectual contribution was significant. The deification of the national state by Hegel had a profound effect on German thought in the 19th century and tended to have the effect of elevating the state above morality, of facilitating an uncritical acceptance of Realpolitik.

By viewing Germany's bid for world power in 1914 as an attempt by the ruling class to ease social tension by means of an aggressive foreign policy, the author is guilty of oversimplification. German militarsm in the Wilhelmine era must be viewed in a wider context: British hostility to Tirpitz's naval programme, the Moroccan crisis, the expansive tendencies of other European powers and so on.

Had Kitchen consulted works by Holger $\mathrm{H}$. Herwig and Joseph Steinberg on the navy and its officer corps he might have benefited from perceptive insights into another part of the officer corps that he neglects entirely. He concentrates solely on the army. The importance of Admiral van Tirpitz's naval programme in strengthening militaristic tendencies at home and in Britan is ignored. Tirpitz was an astute manipulator of public opinion and his naval bills, in contrast to the army bills, were passed by the German parliament without great difficulty.

While the reviewer appreciates the difficulty oi compressing nearly 300 years of the military history of Germany into a single readable book some discussion of the Polish campaign of 1830-31, Italy's role and the indemnity bill in 1866, the Zabern affair, the post war tank development and the North African campaign would have been welcomed. A brief analysis of the army's rôle in Germany's colonial ventures involving a study of the policies of men like Freiherr von Rechenberg, the progessively minded Governor of Tanganyika in the years 1906-11, would have been interesting.

Tactics, and the analysis of battles to illustrate military development, are neglected. For example, Ludendorff's spring offensive of 1918, in which he discovered a 'way through' the Western Front based on infiltration and junior leadership, is mentioned en passant.

A Military History of Germany is so constructed to present an explicit anti militarist thesis. Yet despite the book's many shortcomings and despite his didactism, the author demonstrates that military history, when not of the kings-and-battles brand, can be intellectually stimulating.

- Richard J. Haines.

OORLOGSDAGBOEKIE VAN H. S. OOSTERHAGEN, JANUARIE-JUNIE 1902. Met inleiding, teksversorging en aantekeninge deur $\mathrm{C}$. C. Eloff. Raad vir Geesteswetenskaplike Navorsing, Pretoria, 1976. Met foto's, kaarte en register, pp. 106. Prys: R3,35.

Sedert 1972 verrig die Instituut vir Geskiedenisnavorsing van die RGN, onder leiding van dr C. M. Bakkes, uitstekende werk deur waardevolle geskiedkundige bronnepublikasies die lig te laat sien. Tot nou toe het 'n viertal van hierdie publikasies verskyn wat, tot hede, sowel militêr-historiese as ander fasette van die tydperk 1899-1902 in die Transvaalse geskiedenis belig.

In al hierdie gevalle is enkelinge, soos $\mathrm{H}$. C. Bredell, P. J. du Toit, It-kol S. P. E. Trichard (gewese kommandant van die Transvaalse Staatsartillerie) en - in hierdie geval - Henri Sicco Oosterhagen (Almelo, Nederland, 8 Augustus 1871 — Middelburg, Transvaal, 18 April 1953) aan die woord. Elkeen van hulle het die toenmalige oorlogsgebeure in ons land op hul eie manier ondervind en op hul eie wyse daarop gereageer. Vir elkeen van bogenoemdes het die oorlog aanleiding tot 'n bepaalde optrede gegee. Daar was Du Toit wat na die vyand oorgeloop het en Oosterhagen wat - ofskoon hy hier en daar sy bedenkings gehad het - tot die einde in die veld 